\title{
Resenha
}

Affinity therapy: Nouvelles recherches sur l'autisme

Perrin, M. (Org.)

Rennes, FR: Presses Universitaires de Rennes, 2015, 342 p.

\section{NOVAS PESQUISAS SOBRE O AUTISMO}

\author{
Ariana Lucero \\ Angela Maria Resende Vorcaro \\ Jorge Luis Gonçalves dos Santos
}

DOl: http//dx.doi.org/10.11606/issn. 1981-1624.v20i3p549-555.

O livro Affinity therapy: Nouvelles recherches sur l'autisme nos traz, nas palavras da organizadora desta coletânea, "o que há de novo no tratamento do autismo" (p. 11). Myriam Perrin parte da constatação deveras reafirmada de que todo autista tem suas fixações, ritualizações, obsessões, paixões, para nomear essa particularidade como afinidade. É essa afinidade que deve orientar o tratamento para que seja possível construir uma verdadeira dinâmica subjetiva autista. Contudo, Perrin não se propõe a definir um método de tratamento, mas adota uma perspectiva político-clínica que "coloca a singularidade do falasser no centro de seu fundamento" (p. 11).

Com efeito, trata-se de se contrapor às abordagens cognitivo-comportamentais que negam a subjetividade, fazendo da linguagem unicamente um instrumento de comunicação. Assim, os distúrbios de linguagem não são vistos como sintomas de um transtorno mental

Psicóloga. Doutora pela Universidade Federal de Minas Gerais. Pós-doutoranda do Programa de Pós-Graduação em Psicologia Institucional da Universidade Federal do Espírito Santo/UFES, Vitória, ES, Brasil.

- - Psicanalista. Doutora em Psicologia Clínica pela Pontifícia Universidade Católica de São Paulo-PUCSP. Professora do Departamento de Psicologia da Universidade Federal de Minas Gerais, Belo Horizonte, BH, Brasil.

- - - Psicanalista. Doutor pelo Programa de Pós-Graduação em Teoria Psicanalítica da Universidade Federal do Rio de Janeiro/UFRJ. Professor do Departamento de Psicologia da Universidade Federal do Espírito Santo, Vitória, ES, Brasil. 
[trouble menta], mas como consequência de um déficit cognitivo que deve ser corrigido. É essa concepção do autismo como deficiência [handicap] - predominante na França e nos Estados Unidos - que embasa o uso de métodos educativos no "tratamento" do autismo. Na verdade, nem devemos mais usar o verbo "tratar", mas "educar" (aliás, a educação vai muito além de técnicas de aprendizagem destinadas ao autismo). Porém, essa não é uma discussão avançada no livro em apreço.

A autora questiona o uso que as terapias cognitivo-comportamentais (TCC) fazem das afinidades dos autistas: na melhor das hipóteses, usadas como recompensas ao comportamento adaptado; na pior delas, encaradas como sintomas que reforçam o isolamento e devem, portanto, ser extintas. Perrin sublinha que Hans Asperger, grande referência para os adeptos das TCC, já havia notado que o autista pode estabelecer uma comunicação servindo-se de seu objeto ou de suas preferências, mas parece que "suas observações clínicas que poderiam garantir um lugar ao sujeito - em sua diferença, sua diversidade, seu desejo - ficaram em silêncio" (p. 15).

Ora, Ron Suskind rompeu esse silêncio ao publicar Life, Animated: a story of sidekicks, heroes and autism (2014), relatando como a relação com seu filho autista pode ser restabelecida por meio de filmes da Disney. O depoimento do jornalista do Wall Street Journal, vencedor do prêmio Pulitzer e professor de Harvard, teve grandes repercussões e, no livro Affinity therapy, Suskind (2015) faz uma reflexão lúcida sobre esse acontecimento, voltando os olhares para esses excluídos da sociedade, que, "de fora", do exterior, podem nos mostrar coisas que passam despercebidas. Ao contrário da ideia difundida pelos clínicos de que a paixão de seu filho Owen por filmes era uma obsessão redutora a ser eliminada, Suskind encontrou nos desenhos uma via de acesso aos sentimentos dele. Assistindo aos filmes com o filho, a família deu sentido a frases e expressões que saiam de sua boca, de tal forma que, o que, no início, era uma "terapia Disney", pode agora ser estendida a todos os autistas sob a forma da Affinity therapy.

A primeira parte do livro reúne, portanto, além do artigo de Suskind, depoimentos de mães de autistas que se serviram de desenhos animados para se aproximarem de seus filhos - Valérie Gay e Aurore Cahon; exemplos de instituições que tratam do autismo, respeitando as singularidades e invenções de cada sujeito: La Main à l'Oreille, representada por Mireille Battut; Autisme Pluriel, por Fabrice Bonnet; Pélagie, por Brigitte Garnier e La Tribu de Lulu, por Eugénie Bourdeu; além do texto de Valette-Damase, que faz uma síntese dos principais ensinamentos 
que podemos tirar dessas experiências. Ademais, é preciso enfatizar a possibilidade de aprender com os próprios autistas, de deixar que eles nos apontem o caminho, de modo que o autorrelato de Owen Suskind sobre sua paixão por desenhos da Disney ou a exposição de Alain Ripaud sobre seu interesse pelas plantas carnívoras não podiam ficar de fora. Este, entrevistado por Jean Claude Maleval, é um exemplo de autista tratado simultaneamente por métodos cognitivo-comportamentais e pela psicanálise, reacendendo o debate sobre os tipos de terapias a serem usados no tratamento do autismo. A seguir, Iván Ruiz, diretor do documentário D'autres voix, fala sobre o efeito do mesmo sobre Albert, simultaneamente, protagonista e espectador de sua história. Para encerrar a primeira parte, uma série de livros escritos por autistas ou por suas mães são retomados e comentados por psicanalistas que se servem, em sua maioria, das teorizações de Maleval.

A segunda parte do livro investiga a dimensão propriamente clínica da Affinity therapy, a partir de artigos de terapeutas. O primeiro a se manifestar é, por conseguinte, o terapeuta de Owen, Dan Griffin, que define os Estados Unidos como o lugar de nascimento da terapia por afinidades e a família como sua inventora. Afinal, quando Griffin conhece Owen com treze anos de idade, a família Suskind já fazia uso dos filmes há sete anos, o que mostra que foi um interesse específico da criança que, ao ser partilhado, permitiu que um vínculo fosse recuperado. Griffin, como um bom sidekick, aposta nas metáforas e no valor dos personagens secundários para orientar o tratamento, sem interferir diretamente em um cenário que já estava montado quando ele entrou em cena.

$\mathrm{O}$ artigo de Myriam Perrin apresenta uma pesquisa quantitativa com o objetivo de mensurar a presença de objetos autísticos e de duplos autísticos em vinte e sete sujeitos. É válido observar que a autora aborda a afinidade apenas em relação ao que ela denomina "duplo autístico" e confirma sua função no endereçamento, no contato visual, no tratamento de problemas orais e anais, na diminuição das automutilações, quedas e passagens ao ato. Além disso, Perrin comprova que uma prática voltada a sustentar a invenção subjetiva apazigua a angústia $(85 \%)$ e a relação com o corpo (74\%), amplia o laço social $(78 \%)$ e suscita a animação libidinal (63\%). Ora, esse é um dado bem complicado de mensurar, bem como aquele da relação com a voz e com a linguagem. Aliás, a própria definição de duplo autístico não é objetivamente fornecida, como mereceria um estudo desse tipo, e é simplesmente categorizado enquanto próximos (pais, educadores), pares, personagens animados ou inventados, heróis e animais. Já os objetos autísticos são facilmente identificados: roupas, cobertores, máquinas, pelúcias, objetos duros, sacos, caixas, livros, escritos, desenhos e músicas. 
Embora os três últimos sejam mais difíceis de mensurar, os objetos concretos correspondem a $67 \%$ dos objetos autísticos e esse dado nos interessa sobremaneira ${ }^{2}$. Outro dado importante é o de que as tentativas de limitar as afinidades ou retirar o objeto autístico tiveram como efeito, em $50 \%$ dos casos, o aumento da angústia, das passagens ao ato e das automutilações; e, nos outros $50 \%$, certo apaziguamento. Para a autora, haveria uma tentativa de separação do objeto de gozo que a borda contém, de modo que sua retirada operaria um alívio temporário. É uma pena que, aqui, a psicanalista não tenha feito a distinção entre objeto e duplo. De qualquer forma, fica evidente que, para se separar, é preciso certa alienação, partilhar o objeto, ou, nas palavras de Laurent, "é preciso partir desses objetos e complexificar o mundo da criança a partir dele" (p. 117). Os interesses da criança podem se desenvolver a partir do objeto que serve de apoio para suas invenções. Assim, Laurent traz um exemplo de sua clínica e comenta o caso de Owen Suskind e de outros autistas que, servindo-se de "dispositivos de tratamento da instância da letra", tais como computadores, tablets e celulares, desenvolveram outro tipo de relação com o objeto voz.

Na sequência desses trabalhos, Maleval sublinha a importância do testemunho dos autistas de alto nível para o reconhecimento das afinidades, até então descritas com o termo de conotação pejorativa “obsessões". Já Rabanel destaca que os autistas de "baixo nível" também têm suas "invenções", sendo a partir delas que devemos falar com eles ou, simplesmente, nos aproximarmos (cf. Tendlarz, 2015). Essa é a lição que faz a passagem para a terceira parte do livro, afinidades plurais, em que vinte e seis vinhetas clínicas apontam para a singularidade de cada sujeito autista, sem, no entanto, se deterem em uma articulação teórica consistente com a proposta de uma terapia por afinidade. Não apenas as afinidades, mas as práticas são plurais e, muitas vezes, sem metodologia. Isso nos leva a interrogar tanto a proibição de psicanalistas atenderem autistas na França quanto o lugar do caso clínico na psicanálise. Voltaremos a esses temas.

$\mathrm{Na}$ quarta parte, Sérgio Laia retoma o caráter afetivo do autismo, definido inicialmente, recordemos, como transtorno afetivo do desenvolvimento, para relacioná-lo com o quantum de afeto freudiano, impossível de ser quantificado. Ele aponta que o DSM-V apresenta o espectro autista em termos quantitativos, mas esse não é um critério científico exato, justamente porque algo escapa às medidas objetivas conhecidas. O neologismo lacaniano dit-mension refere-se aos efeitos do dizer, da linguagem, no corpo. Essa dimensão corporal não pode ser reduzida ao cérebro ou às 
neurociências, como almeja o DSM, pois o afeto, o gozo, não pode ser localizado ou mensurado. Talvez seja justamente por isso que os critérios diagnósticos do autismo são tão variáveis, dificultando os estudos genéticos e etiológicos, tal como expõe Ariane Giacobino. Essa autora questiona o aumento no número de autistas e sai do dualismo causas genéticas $\mathrm{X}$ causas ambientais, a partir do conceito de epigenoma: "o epigenoma engloba as mudanças de expressão dos genes devido aos fatores ambientais sem que, por isso, a sequência de DNA ela mesma seja modificada" (p. 269). Assim, as pesquisas que tentam encontrar uma causa única para o autismo devem ser interpretadas com cautela, o que não ocorre na divulgação das mesmas para o grande público. Por fim, o trabalho de Gilles Chatenay encerra a discussão do autismo com a ciência, relembrando que a singularidade da fala/da linguagem no sujeito humano interroga a ciência em sua tentativa de generalização.

$\mathrm{Na}$ quinta parte, supostamente dedicada às práticas institucionais, apenas o artigo de Jean-Pierre Rouillon defende as instituições como lugar onde o sujeito pode inventar uma maneira inédita de se colocar no mundo, desde que respeitado em sua relação com a linguagem. A psicanálise seria o método que permite à fala peculiar do autista transformar-se em um saber a ser expandido para além da instituição, mas com seu suporte. O problema do método é, com efeito, o tema abordado em todos os trabalhos dessa parte. Primeiramente, Detienne, Possoz e Fouchet se perguntam se a Affinity therapy poderia ser uma prática recomendada pelas Autoridades de Saúde ${ }^{3}$ e chegam a duas respostas antagônicas: não, já que não possui uma metodologia padronizada que segue os critérios científicos; sim, pois, do ponto de vista da ética atual, considera as "preferências" do sujeito, colocando-o no centro das decisões que lhe concernem. Essa falta de consenso poderia ser resolvida de duas maneiras: fazer a Affinity therapy passar por uma avaliação padronizada - o que, de certa forma, é a tentativa em jogo na pesquisa de Perrin -, ou, modificar as formas de avaliação dos métodos. Neste caso, os autores sugerem que os estudos de casos devem ter valor reconhecido pela ciência, o que nos faz retornar sobre a terceira parte do livro, refletindo sobre o valor das exposições ali feitas, seja do ponto de vista das ciências seja daquele da psicanálise. Por sua vez, o artigo de Flemal, Senay e Fouchet faz uma reflexão sobre o manejo clínico das "preferências" (afinidades) e também lança uma luz sobre alguns problemas dos relatos de casos presentes no livro. 
Em meio a essa polêmica metodológica que tanto afeta a psicanálise, Alexandre Stevens assume a teorização lacaniana e denomina a invenção dos autistas de "invenção sintomática, que se presta bem à palavra Affinity" (p. 304). Nesse sentido, é a ética do caso a caso que deve guiar as maneiras dessas invenções integrarem o campo social, tendo em vista que, às vezes, elas podem servir, pelo contrário, à proteção do autista das demandas externas. Com certa ressalva em relação ao uso da palavra "método", o autor insiste na extração do gozo como forma de conviver com a afinidade e não é tão otimista quanto os demais colaboradores do livro. Ainda assim, não podemos esquecer que o sinthoma, ao qual se referem às invenções subjetivas, faz laço social e nos perguntamos se a articulação das afinidades com a invenção sintomática não mereceria uma análise mais cuidadosa? Será que todas as afinidades são invenções? Ou elas podem se tornar invenções? A psicanálise não poderia desenvolver um método de trabalho com autistas, para além de uma ética do singular, que já é sua orientação clínica por excelência?

Gostaríamos de encerrar esta resenha com essas perguntas, mas faz-se imperativo comentar a conclusão de Perrin que, explicitamente esquivando-se da questão metodológica - "a terapia por afinidades se torna o denominador comum, não de um método, mas de um saber-fazer com o autista" (p. 311) -, acaba por furtar-se também a uma delimitação da estrutura clínica do autismo. Fica claro que certo encantamento por essas subjetividades autistas mobilizou a organização desse livro, trazendo em sua esteira a questão política, retomada no posfácio de Maleval. Ali, novamente aparece a contraposição às abordagens cognitivo-comportamentais que desconsideram a singularidade dos sujeitos e o objetivo de favorecer o retorno de uma abordagem psicodinâmica do autismo. Mas é esse todo o trabalho que a psicanálise tem a fazer no campo do autismo? Reconhecemos esse livro como um primeiro passo na direção da retomada de um espaço do qual a psicanálise vem sendo retirada em alguns países, em especial, na França e nos Estados Unidos. A proposta de quantificação, tanto pelo volume de artigos que compõem o livro, quanto na própria pesquisa exposta por Perrin, pode ser encarada como uma tentativa de restabelecer uma comunicação da psicanálise com a ciência, tirando a psicanálise de seu lugar autista, tão criticado por seus opositores. Contudo, a psicanálise tem seu lugar de extimidade em relação à ciência e deve manter sua vocação clínica de interrogar o saber que se apresenta como verdade. Isso não quer dizer que ela

554 Estilos clin., São Paulo, v. 20, n. 3, set./dez. 2015, 549-555. 
não tenha que expor um método de trabalho consistente, acessível e passível de ser reconhecido por todos. E, aqui, retomamos a discussão a respeito do caso clínico em psicanálise, bem como acreditamos que possam surgir novas contribuições.

\section{NOTAS}

1. Toda a história de Owen, como o próprio título do livro de Ron Suskind explicita, gira em torno do papel essencial dos sidekicks na vitória dos heróis. Em português, não temos uma palavra específica para designar esse fiel companheiro, ajudante, enfim, esse personagem que se coloca sempre ao lado dos heróis. Já os franceses adotam o termo faire-valoir.

2. A pesquisa "O uso de objetos na direçâo de tratamento psicanalítico da criança autista", desenvolvida no Programa de Pós-graduação em Psicologia Institucional da UFES, com o apoio da FAPES/CAPES, visa a esclarecer a função que os objetos concretos podem ter no tratamento do autismo.

3. Os autores têm em vista especialmente três órgãos estatais: a Haute Autorité de Santé (HAS), na França; o National Institute for Health and Care Excellence (NICE), no Reino Unido; e o Belgian Health Care Knowledge Centre (KCE), Bélgica.

luceroariana@yahoo.com.br

Av. Fernando Ferrari, 514 29075-910 - Vitória - ES - Brasil.

angelavorcaro@uol.com.br Av. Antônio Carlos, 6.627 31270-901 - Belo Horizonte - MG - Brasil.

santos-jorgeluis@hotmail.com

Av. Fernando Ferrari, 514 29075-910 - Vitória - ES - Brasil.

Recebido em novembro/2105. Aceito em dezembro/2015. 